\title{
PEMBERDAYAAN MASYARAKAT TANI MELALUI PELATIHAN MINI GARDEN DI DESA TELAGA LUHUR
}

\author{
Dewi Surani $^{1 *}$, Dina Awaliyah ${ }^{2}$, Nova Novianti ${ }^{3}$, Emil Bari Sohibul Ulum $^{4}$, Kurniawati ${ }^{5}$ \\ 1,2,3,4,5 Universitas Bina Bangsa \\ suranidewiahead@gmail.com
}

\begin{abstract}
ABSTRAK
Penghijauan merupakan salah satu kegiatan penting yang harus dilaksanakan secara konseptual dalam menangani krisis lingkungan. Desa Telaga Luhur Kec Waringin Kurung, Serang-Banten merupakan salah satu desa yang cukup aktif dalam mendukung program penghijauan. Dalam upaya penyelamatan lingkungan, masyarakat bersama stakeholder terkait telah melakukan berbagai kegiatan penghijauan. Kegiatan bertujuan untuk mengkaji tentang bagaimana bentuk keterlibatan masyarakat dalam upaya penghijauan pada kawasan desa sidilem. Masyarakat sebetulnya telah terlibat dalam proses perencanaan, penyediaan, pemeliharaan, serta pengawasan kegiatan penghijauan. Namun, masyarakat menilai kondisi ruang hijau di desa sidelem saat ini sudah sangat minim. Kegiatan penghijauan dilakukan dengan berbagai tujuan, antara lain: untuk menambah nilai ekologi, manambah nilai estetika, mendapatkan manfaat ekonomi, serta alasan untuk mendukung program pemerintah. Keberadaaan stakeholder yang terdiri dari Pemerintah Kota, Pemerintah Kelurahan, Lembaga Non Pemerintah, Swasta/CSR, dan Komunitas/Akademisi telah berkontribusi besar membantu perkembangan kegiatan penghijauan di wilayah pengabdian.
\end{abstract}

Kata kunci : Penghijauan, Desa

\begin{abstract}
Reforestation is one of the important activities that must be implemented conceptually in dealing with environmental crises. Telaga Luhur Village, Waringin Kurung Sub-district, Serang-Banten is one of the villages that is quite active in supporting reforestation programs. In an effort to save the environment, the community together with relevant stakeholders have carried out various reforestation activities. The activity aims to examine how the form of community involvement in reforestation efforts in the Sidilem village area. The community has actually been involved in the process of planning, providing, maintaining, and supervising reforestation activities. However, the community considers that the condition of green space in Sidelem village is currently very minimal. Reforestation activities are carried out with various objectives, including: to add ecological value, add aesthetic value, obtain economic benefits, as well as reasons to support government programs. The presence of stakeholders consisting of the City Government, Village Government, Non-Governmental Institutions, Private/CSR, and Community/Academics has contributed greatly to the development of reforestation activities in the service area.
\end{abstract}

Keywords : Greenery, Village

\section{PENDAHULUAN}

Pertanian di Indonesia merupakan salah satu sektor kunci perekonomian Indonesia. Meskipun kontribusi sektor pertanian terhadap Produk Domestik Bruto Nasional telah menurun secara signifikan dalam setengah abad terakhir, saat ini sektor pertanian masih memberikan pendapatan bagi sebagian besar rumah tangga Indonesia. Pada tahun 2013, sektor pertanian 
Prosiding The 1st National Conference on Applied Business, Education, \& Technology (NCABET)",

Unversitas Bina Bangsa 2021

DOI Article : 10.46306/ncabet.v1i1.57

menyumbang 14,43\% dari PDB nasional, sedikit mengalami penurunan dibandingkan satu dekade sebelumnya (2003) yang mencapai 15,19\%. Pada tahun 2012, sektor ini menyediakan lapangan kerja untuk sekitar 49 juta orang Indonesia, yang mewakili $41 \%$ dari total angkatan kerja di negara ini.

Saat ini, sekitar 30\% lahan Indonesia digunakan untuk pertanian. Sektor pertanian Indonesia ditinjau dan diatur oleh Kementerian Pertanian Republik Indonesia. Umumnya, sektor pertanian di Indonesia terdiri dari dua jenis berdasarkan skala per 1 meter:

1. Perkebunan besar baik milik negara maupun perusahaan swasta

2. Produksi petani kecil, kebanyakan rumah tangga yang melakukan pertanian tradisional. Perkebunan besar cenderung fokus pada komoditas ekspor; seperti minyak sawit dan karet, sementara petani skala kecil fokus pada komoditas hortikultura untuk memasok konsumsi makanan masyarakat lokal dan regional, seperti beras, kedelai, jagung, buah-buahan dan sayuran.

Dan dalam rangka mewujudkan Indonesia yang berdaulat, mandiri, dan berkepribadian berlandaskan gotong-royong, salah satunya adalah dengan melakukan pemberdayaan terhadap masyarakat petani khususnya di wilayah-wilayah pedesaan yang memiliki populasi yang cukup besar. Pemberdayaan masyarakat biasa dipahami atau diartikan sebagai proses mengembangkan, memandirikan, menswadayakan, memperkuat posisi tawar menawar masyarakat lapisan bawah terhadap kekuatan-kekuatan penekan di segala bidang dan sektor kehidupan. Ada pula pihak lain yang menegaskan bahwa pemberdayaan adalah proses memfasilitasi warga masyarakat secara bersama-sama pada sebuah kepentingan bersama atau urusan yang secara kolektif dapat mengidentifikasi sasaran, mengumpulkan sumber daya, mengerahkan suatu kampanye aksi dan oleh karena itu membantu menyusun kembali kekuatan dalam komunitas.

\section{METODE PELAKSANAAN}

Kegiatan Pengabdian kepada masyarakat ini dilaksanakan pada tanggal 04 Agustus 2021

\begin{tabular}{|l|l|l|l|}
\hline Tahap Kegiatan & Kegiatan & Metode & Hasil \\
\hline Tahap & $\begin{array}{l}\text { Menyiapkan lahan } \\
\text { Perencanaan }\end{array}$ & $\begin{array}{l}\text { Diskusi dengan teman } \\
\text { kelompok }\end{array}$ & $\begin{array}{l}\text { Membersihkan lahan di tempat } \\
\text { kelurahan di kantor desa telaga } \\
\text { luhur }\end{array}$ \\
\hline Tahap Persiapan & $\begin{array}{l}\text { Membeli bibit } \\
\text { tanaman }\end{array}$ & $\begin{array}{l}\text { Diskusi dengan teman } \\
\text { kelompok }\end{array}$ & $\begin{array}{l}\text { Memindahkan bibit tanaman } \\
\text { kedalam polybag }\end{array}$ \\
\hline
\end{tabular}




\begin{tabular}{|c|c|c|c|}
\hline $\begin{array}{l}\text { Tahap } \\
\text { pelaksanaan }\end{array}$ & $\begin{array}{l}\text { Membuat tempat } \\
\text { untuk menyimpan } \\
\text { tanaman yang } \\
\text { terbuat dari kayu }\end{array}$ & $\begin{array}{l}\text { Melakukan } \\
\text { pengecekan, } \\
\text { menyiram, \& memberi } \\
\text { pupuk tanaman }\end{array}$ & $\begin{array}{l}\text { Sudah ada beberapa tanaman } \\
\text { yang membuahkan hasil / } \\
\text { berbuah }\end{array}$ \\
\hline
\end{tabular}

\section{HASIL DAN PEMBAHASAN}

Lahan pertanian menjadi salah satu sumber mata pencaharian bagi warga yang tinggal di Desa Telaga Luhur. Namun, akibat kondisi tanah yang kekurangan air, warga hanya bisa menanam tanaman pangan pokok saja seperti padi saat akan musim hujan, dan selama kemarau berlangsung warga menanam tanaman palawijaya seperti cabai atau beberapa buah-buahan yang tidak memerlukan banyak air seperti pepaya.

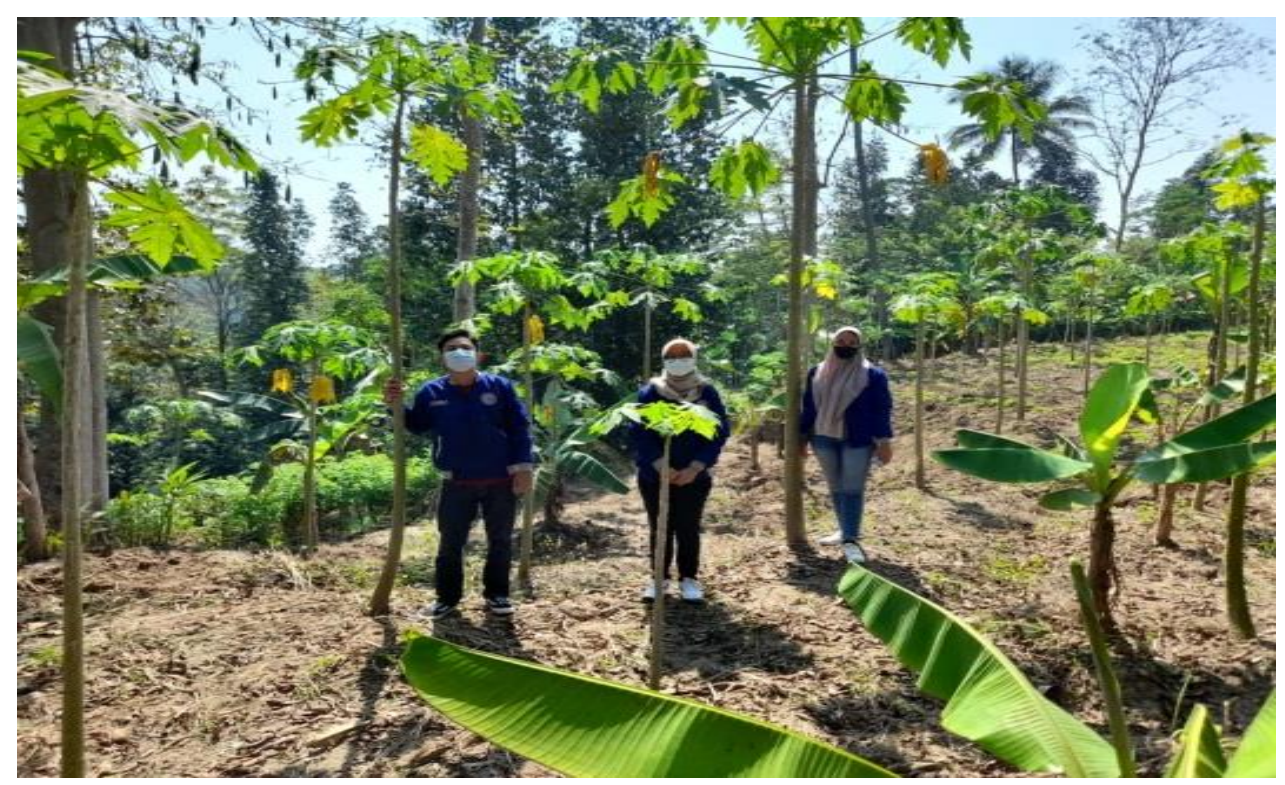

Gambar 1. Lahan Perkebunan Milik Warga

Disamping itu, Tim Pengabdian Universitas Bina Bangsa yang melakukan kegiatan pengabdian di Desa Telaga Luhur memiliki kesempatan dalam membantu proses memanen hasil tanaman cabai di salah satu lahan pertanian milik warga. Salah satu lahan yang dikunjungi ini bisa menghasilkan cabai hingga 1,4-ton dalam satu kali panen, dimana harga yang dipatok untuk cabai tersebut yaitu sebesar Rp. 20.000, - per kg. Menurut salah satu pemilik lahan pertanian di Desa Telaga Luhur, dalam satu tahun pohon cabai bisa dipanen dua hingga tiga kali. Dimana setelah panen berlangsung, warga menjual hasil panennya kepada pengepul, warga sekitar yang tidak memiliki lahan pertanian, dan mandiri ke pasar. Bahkan beberapa 
Prosiding The 1st National Conference on Applied Business, Education, \& Technology (NCABET)",

Unversitas Bina Bangsa 2021

DOI Article : 10.46306/ncabet.v1i1.57

desa sekitar datang ke lokasi langsung saat musim panen tiba untuk membeli cabai yang dihasilkan Desa Telaga Luhur.

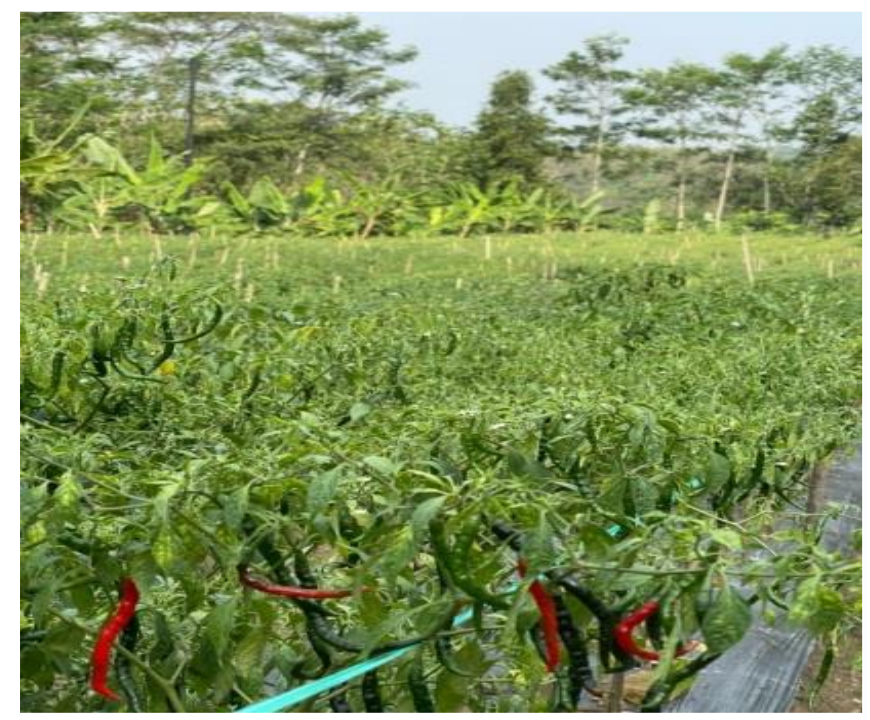

Gambar 2. Lahan Tanaman Cabai Milik Salah Satu Warga Desa Telaga Luhur

Pada tanggal 24 Juli 2021 Tim Pengabdian Masyarakat Universitas Bina Bangsa melakukan survey di salah satu pemukiman warga yang ada di Desa Telaga Luhur tepatnya di Kampung Sidilem, disana terdapat lahan pertanian yang cukup luas namun keadaan tanah di desa tersebut tandus akibat kekurangan sumber air, serta belum optimalnya program pemanfaatan lahan, sehingga lahan pertanian warga desa tersebut hanya bisa ditanami beberapa tanaman saja seperti pepaya, timun, cabai, dan beberapa bumbu dapur lainnya. Maka dari itu Tim Pengabdian Masyarakat UNIBA berinisiatif untuk membuat mini garden.

Untuk memenuhi beberapa kebutuhan yang diperlukan dalam proses menanam salah satu diantaranya yaitu pupuk tanaman, warga bisa mendapatkannya di salah satu organisasi yang dibentuk di Desa Telaga Luhur yaitu GAPOKTAN (Gabungan Kelompok Tani). GAPOKTAN sendiri merupakan organisasi yang dibentuk untuk menyediakan pupuk dan bibit tanaman yang nantinya dijual kepada warga desa dengan harga yang lebih murah dibandingkan harga dipasaran. 

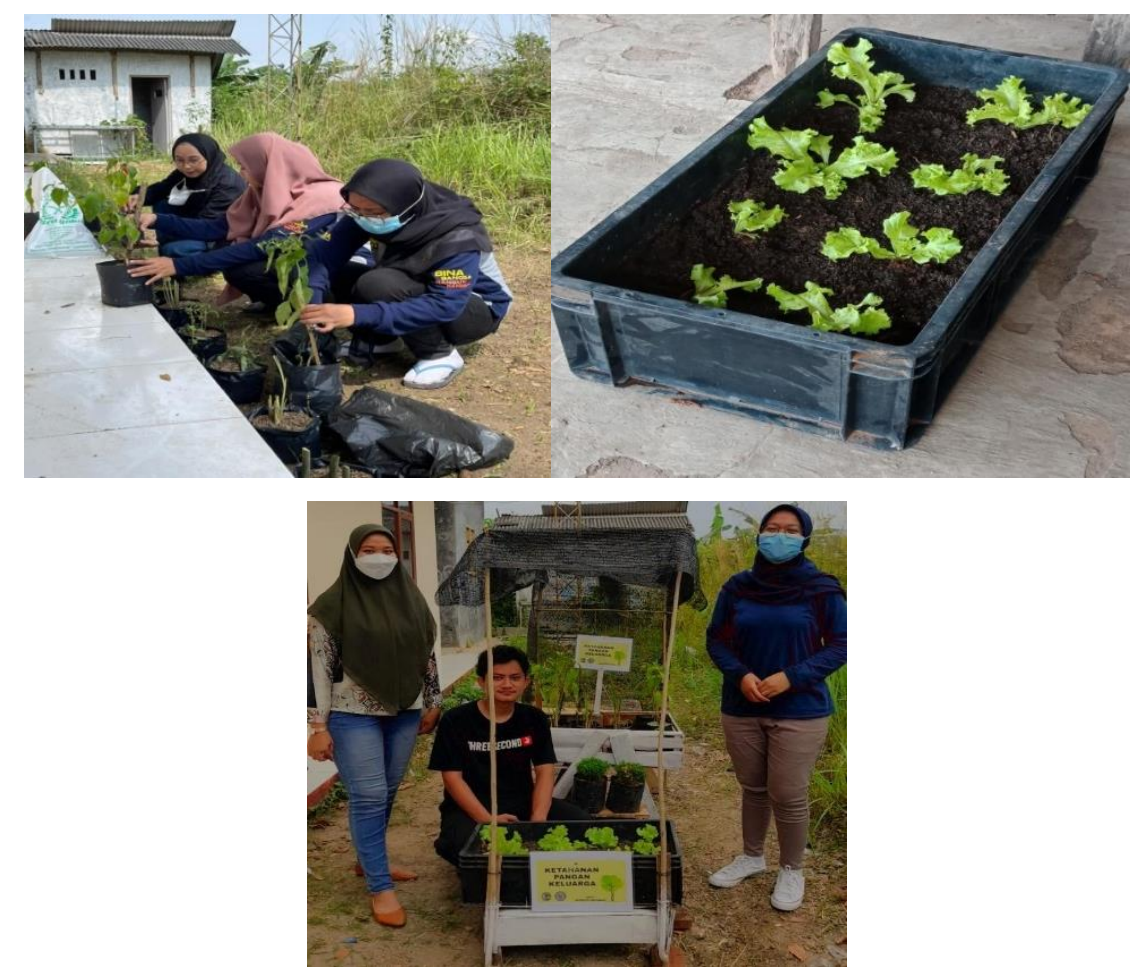

Gambar 3. Pelatihan GAPOKTAN

\section{KESIMPULAN DAN SARAN}

Lahan pertanian menjadi salah satu sumber mata pencaharian warga Desa Telaga Luhur. Namun, akibat kondisi tanah yang kekurangan air, warga hanya bisa menanam tanaman pangan pokok seperti padi saat akan musim hujan dan selama kemarau berlangsung warga menanam tanaman palawija seperti cabai atau beberapa buah-buahan yang tidak memerlukan banyak air seperti pepaya.

Untuk memenuhi beberapa kebutuhan yang diperlukan dalam proses menanam dimana salah satu diantanya yaitu pupuk tanaman, warga bisa mendapatkannya di salah satu organisasi yang dibentuk di Desa Telaga Luhur yaitu GAPOKTAN (Gabungan Kelompok Tani). GAPOKTAN sendiri merupakan organisasi yang dibentuk untuk menyediakan pupuk dan bibit tanaman yang nantinya dijual kepada warga desa dengan harga yang lebih murah dibandingkan harga dipasaran.

\section{UCAPAN TERIMAKASIH}

Kami ucapkan terimakasih kepada semua pihak yang sudah membantu dan turut terlibat dalam kelancaran kegiatan pengabdian di Desa Telaga Luhur ini, baik dalam bentuk fasilitas, dana, maupun tenaga. 
Prosiding The 1st National Conference on Applied Business, Education, \& Technology (NCABET)" Unversitas Bina Bangsa 2021

DOI Article : 10.46306/ncabet.v1i1.57

\section{DAFTAR PUSTAKA}

https://id.wikipedia.org/wiki/Pertanian_dan_perkebunan_di_Indonesia

http://www.ejournal.fisip.unjani.ac.id/index.php/jurnal-academia-praja/article/view/69/57 http://repository.ut.ac.id/4425/

https://dispertan.bantenprov.go.id/lama/read/berita/183/Produk-Hortikultura-di-BantenTerus-Meningkat.html

https://jurnal.untirta.ac.id/index.php/jat/article/view/5537 